\title{
Arenimonas daejeonensis sp. nov., isolated from compost
}

\author{
Correspondence \\ Hee-Mock Oh \\ heemock@kribb.re.kr \\ Sung-Taik Lee \\ e_stlee@kaist.ac.kr
}

\author{
Long Jin, ${ }^{1}$ Kwang Kyu Kim, ${ }^{2}$ Kwang-Guk An, ${ }^{3}$ Hee-Mock Oh ${ }^{1}$ \\ and Sung-Taik Lee ${ }^{4}$
}

\begin{abstract}
${ }^{1}$ Environmental Biotechnology Research Centre, Korea Research Institute of Bioscience \& Biotechnology, 125 Gwahak-ro, Yuseong-gu, Daejeon 305-806, Republic of Korea

${ }^{2}$ Korean Collection for Type Cultures, Biological Resource Centre, Korea Research Institute of Bioscience \& Biotechnology, 125 Gwahak-ro, Yuseong-gu, Daejeon 305-806, Republic of Korea

${ }^{3}$ Department of Bioscience and Biotechnology, College of Biological Science and Biotechnology, Chungnam National University, Daejeon 305-764, Republic of Korea

${ }^{4}$ Department of Biological Sciences, Korea Advanced Institute of Science and Technology, 335 Gwahak-ro, Yuseong-gu, Daejeon 305-701, Republic of Korea
\end{abstract}

\begin{abstract}
A Gram-negative, aerobic, motile and rod-shaped bacterium, designated strain $\mathrm{T} 7-07^{\top}$, was isolated from compost in Daejeon, Korea. Phylogenetic analysis based on 16S rRNA gene sequencing showed that strain $\mathrm{T} 7-07^{\top}$ had $99.0 \%$ gene sequence similarity with Arenimonas malthae KACC $14618^{\top}$ and $94.7-95.9 \%$ with other recognized species of the genus Arenimonas. Cells formed creamy white to yellowish colonies on R2A agar and contained Q-8 as the predominant ubiquinone, $\mathrm{C}_{15: 0}$ iso, $\mathrm{C}_{16: 0}$ iso, $\mathrm{C}_{17: 1}$ iso $\omega 9 \mathrm{c}$ and $\mathrm{C}_{11: 0}$ iso $3-\mathrm{OH}$ as the major fatty acids, and diphosphatidylglycerol, phosphatidylethanolamine, phosphatidylglycerol, phosphatidylmethylethanolamine and an unknown aminolipid as the major polar lipids. The DNA $\mathrm{G}+\mathrm{C}$ content of strain $\mathrm{T} 7-07^{\top}$ was $68.3 \mathrm{~mol} \%$. DNA-DNA reassociation experiments between T7-07 ${ }^{\top}$ and Arenimonas malthae KACC $14618^{\top}$ resulted in a mean relatedness value of $22.2 \%$. Combined genotypic and phenotypic data supported the conclusion that the strain T7-07 represents a novel species, for which the name Arenimonas daejeonensis sp. nov. is proposed. The type strain is $\mathrm{T}^{-07}-07^{\top}\left(=\mathrm{KCTC} 12667^{\top}=\mathrm{DSM} 18060^{\top}\right)$.
\end{abstract}

Compost is an important source for the isolation of thermophiles and moderate thermophiles. However, to date, only moderate thermophiles have been found and most of them belong to the genera Bacillus, Geobacillus and Clostridium and other related genera (Lajudie, 1956; Kane \& Mullins, 1973; Winker \& Woese, 1991; Moriya et al., 2011). The genus Arenimonas, which was proposed by Kwon et al. (2007), is a member of the family Xanthomonadaceae in the class Gammaproteobacteria, and at the time of writing, the genus Arenimonas comprised four recognized species isolated from different environmental sources. Arenimonas compost $i$ KCTC $12666^{\mathrm{T}}$ was isolated from compost (Jin et al., 2007), A. donghaensis KACC $11381^{\mathrm{T}}$ from an anaerobic sludge blanket reactor (Kwon et al., 2007), A. malthae CC-JY- $1^{\mathrm{T}}$ from a soil sample (Young et al., 2007), and $A$. oryziterrae KACC $14607^{\mathrm{T}}$ from a field of rice (Aslam et al., 2009). The type species of this genus is A. donghaensis.

The GenBank/EMBL/DDBJ accession number for the 16S rRNA gene sequence of strain $\mathrm{T}^{-}-07^{\top}$ is $\mathrm{AM} 229325$.

A supplementary table and a supplementary figure are available with the online version of this paper.
Strain $77-07^{\mathrm{T}}$ was isolated during an investigation of the bacterial community present in compost from a farm in Daejeon, Korea. A $1 \mathrm{~g}$ compost sample was collected and serially diluted in $0.85 \%$ saline solution. Aliquots of each serial dilution were spread on R2A agar (Difco) and incubated at $30{ }^{\circ} \mathrm{C}$ for 7 days. A creamy white to yellowish colony, designated strain $\mathrm{T} 7-07^{\mathrm{T}}$, was isolated and subcultivated on $\mathrm{R} 2 \mathrm{~A}$ agar at $30^{\circ} \mathrm{C}$ for $48 \mathrm{~h}$. Based on phylogenetic, phenotypic and chemotaxonomic analysis, it is suggested that the new strain represents a novel species of the genus Arenimonas. For further classification, strain $\mathrm{T} 7-07^{\mathrm{T}}$ was investigated using a polyphasic approach.

The Gram reaction was performed with $2 \%(w / v)$ crystal violet, iodine fixation and decolorization. Decolorization was accomplished using $95 \%$ ethanol followed by a distilled water wash and counterstaining with safranin (Gerhardt et al., 1994). Cell morphology and motility were observed under a phase-contrast microscope (Optiphot, Nikon; $1000 \times$ magnification) with cells grown on R2A agar for 1-3 days. The presence of flagella was determined by transmission electron microscopy (JEM-10111; JEOL) 
after negative staining with $2 \%(\mathrm{w} / \mathrm{v})$ uranyl acetate. Oxidase activity was tested using $1 \%$ tetramethyl-p-phenylenediamine (Tarrand \& Gröschel, 1982) and catalase activity was tested using $3 \% \mathrm{H}_{2} \mathrm{O}_{2}$. Growth was investigated at 4, $10,15,20,25,30,32,37,42$ and $45{ }^{\circ} \mathrm{C}$, in the presence of $1,2,3$ and $5 \%(\mathrm{w} / \mathrm{v}) \mathrm{NaCl}$ and at $\mathrm{pH} 5-10$ in increments of $1 \mathrm{pH}$ unit. The following biological buffers were used to adjust the pH: $\mathrm{Na}_{2} \mathrm{HPO}_{4} / \mathrm{NaH}_{2} \mathrm{PO}_{4}$ for $\mathrm{pH} 5-7$ and $\mathrm{Na}_{2} \mathrm{CO}_{3} / \mathrm{NaHCO}_{3}$ for pH 8-10 (Gomori, 1955; Bates \& Bower, 1956). Degradation of DNA was investigated using DNA agar (Difco) supplemented with $0.01 \%$ toluidine blue (Merck). Degradation of casein, chitin and starch (Atlas, 1993) and cellulose and xylan (Ten et al., 2004) was also examined. Antibiotic-susceptibility tests were performed in duplicate using filter-paper discs containing the following: ampicillin $(10 \mu \mathrm{g})$, erythromycin $(30 \mu \mathrm{g})$, kanamycin $(30 \mu \mathrm{g})$, neomycin $(30 \mu \mathrm{g})$, penicillin $\mathrm{G}(10 \mathrm{U})$ and streptomycin $(10 \mu \mathrm{g})$ (Sigma). Carbon source utilization tests, acid production tests and additional physiological analyses were performed using API 20NE (bioMérieux), Biolog GN2 (Biolog), API 50CH (bioMérieux) and API
ZYM (bioMérieux) galleries according to the manufacturers' instructions.

Fatty acid methyl esters were prepared from bacteria grown in R2A medium for 2 days at $30{ }^{\circ} \mathrm{C}$. Samples were saponified, methylated and extracted according to the protocol of the Sherlock Microbial Identification System (MIDI). The fatty acids were analysed by GC (6890; Hewlett Packard) and were identified according to the Microbial Identification software package (Sasser, 1990). Identification and comparison were made using the Aerobe (TSBA version 3.9) database. Isoprenoid quinones were analysed by HPLC as described by Groth et al. (1996). Polar lipids were extracted, examined by two-dimensional TLC and identified using published procedures (Minnikin et al., 1977).

Extraction of genomic DNA, PCR-mediated amplification of the 16S rRNA genes and sequencing of purified PCR products were carried out according to procedures described by Rainey et al. (1996). The 16S rRNA gene sequences were aligned with published sequences retrieved from EMBL using CLUSTAL_x (Thompson et al., 1997) and

Table 1. Phenotypic and chemotaxonomic characteristics that distinguish strain T7-07 ${ }^{\top}$ from other species of the genus Arenimonas

Strains: 1 , T7 $-07^{\mathrm{T}}$; 2, A. malthae KACC $14618^{\mathrm{T}}$; 3, A. composti KCTC $12666^{\mathrm{T}}$; 4, A. donghaensis KACC $11381^{\mathrm{T}}$; 5, A. oryziterrae $\mathrm{KACC} 14607^{\mathrm{T}}$. All data from this study unless indicated. All strains were positive for acid phosphatase, alkaline phosphatase, $\alpha$-chymotrypsin, esterase (C4), esterase lipase (C8) and naphthol-AS-BI-phosphohydrolase. All strains were negative for nitrate and nitrite reduction, indole production, glucose fermentation, aesculin hydrolysis, $N$-acetyl- $\beta$-glucosaminidase, $\alpha$-fucosidase, $\alpha$-galactosidase, $\beta$-galactosidase, $\beta$-glucuronidase, $\alpha$-glucosidase, $\beta$ glucosidase and $\alpha$-mannosidase. +, Positive; - , negative; AL, unknown aminolipid; DPG, diphosphatidylglycerol; PE, phosphatidylethanolamine; PG, phosphatidylglycerol; PL, unknown phospholipid; PME, phosphatidylmethylethanolamine.

\begin{tabular}{|c|c|c|c|c|c|}
\hline Characteristic & 1 & 2 & 3 & 4 & 5 \\
\hline Colony colour & $\begin{array}{c}\text { Creamy white to } \\
\text { yellowish }\end{array}$ & $\begin{array}{c}\text { Transparent to } \\
\text { brownish }\end{array}$ & $\begin{array}{c}\text { Creamy white to } \\
\text { brownish }\end{array}$ & Yellowish white & $\begin{array}{c}\text { Yellowish to creamy } \\
\text { white }\end{array}$ \\
\hline Temperature range $\left({ }^{\circ} \mathrm{C}\right)$ & $15-37$ & $15-37$ & $20-42$ & $4-37$ & $15-37$ \\
\hline $\begin{array}{l}\text { Growth range of } \mathrm{NaCl}(\% \text {, } \\
\text { w/v) }\end{array}$ & $0-3.0$ & $0-2.0^{*}$ & $0-2.0$ & $0-3.0 \dagger$ & $0 \ddagger$ \\
\hline Urease & + & - & + & - & - \\
\hline Gelatin hydrolysis & - & + & - & + & - \\
\hline \multicolumn{6}{|l|}{ Enzyme activities: } \\
\hline Lipase (C14) & - & - & - & - & + \\
\hline Leucine arylamidase & + & + & + & - & + \\
\hline $\begin{array}{l}\text { DNA G }+C \text { content } \\
(\mathrm{mol} \%)\end{array}$ & 68.3 & $70.4^{*}$ & 70.8 & $65.0 \dagger$ & $65.8 \ddagger$ \\
\hline
\end{tabular}

${ }^{\star}$ Data taken from Young et al. (2007).

$\dagger$ Data taken from Kwon et al. (2007).

\$Data taken from Aslam et al. (2009). 


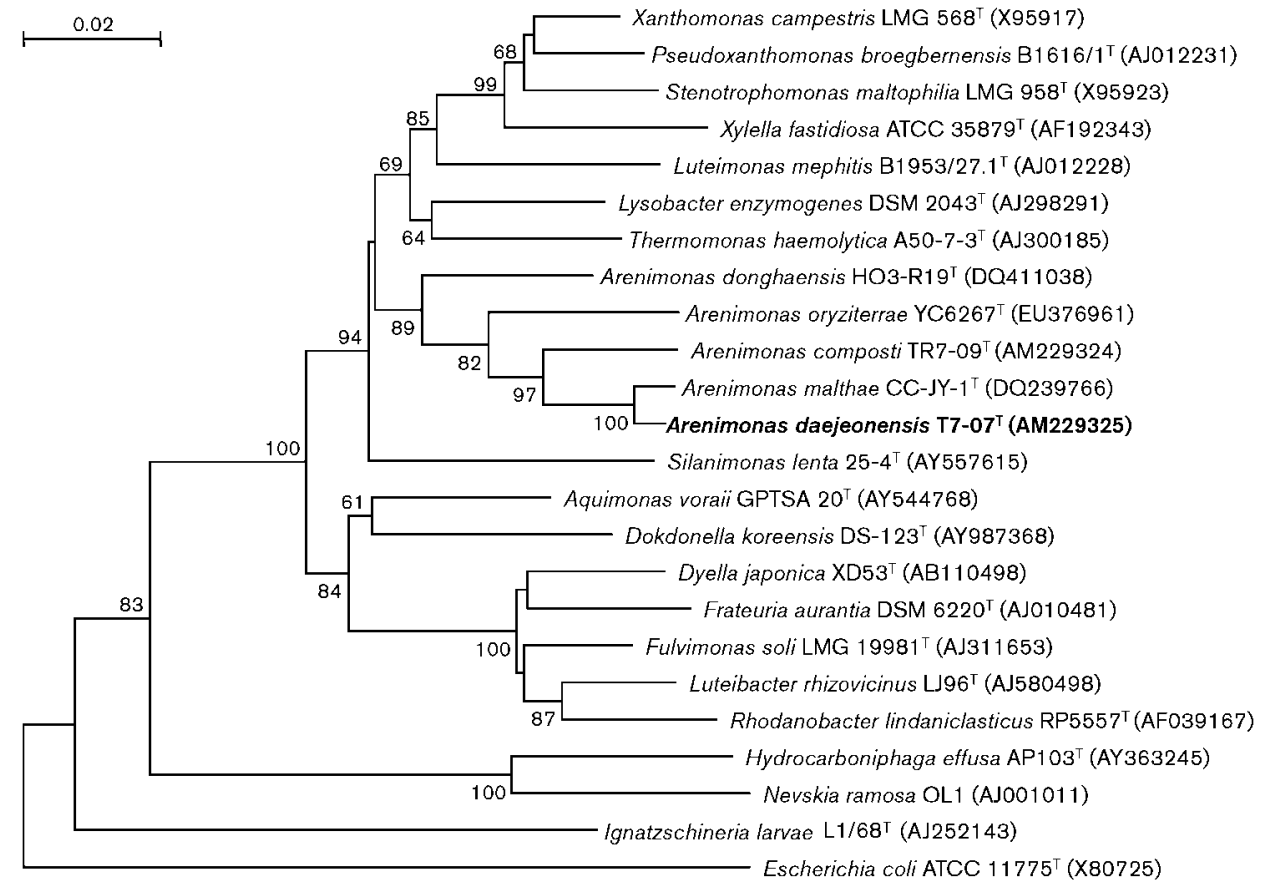

Fig. 1. Phylogenetic tree based on $16 \mathrm{~S}$ rRNA gene sequences using the neighbour-joining method (Saitou \& Nei, 1987) showing the positions of strain $T 7-07^{\top}$ and related taxa. Numbers at branching points refer to bootstrap values (1000 resamplings, only values $>50 \%$ shown). Bar, 2 substitutions per 100 nt positions.

edited using BIOEDIT (Hall, 1999). The phylogenetic tree was constructed on the basis of the neighbour-joining method (Saitou \& Nei, 1987); distances were estimated using the Kimura two-parameter model (Kimura, 1983) with MEGA version 3.1 (Kumar et al., 2004). The resultant neighbour-joining tree topology was evaluated by bootstrap analysis (Felsenstein, 1985) based on 1000 resampled datasets. DNA G $+\mathrm{C}$ content was determined by HPLC after hydrolysis as described by Tamaoka \& Komagata (1984) and non-methylated $\lambda$ DNA (Sigma) was used as a standard. DNA-DNA hybridization to determine genomic relatedness was performed fluorometrically by the method of Ezaki et al. (1989) using DNA probes labelled with photobiotin (A1935; Sigma) and microdilution wells (96well microplate; Greiner Bio-one).

Strain $\mathrm{T} 7-07^{\mathrm{T}}$ formed visible colonies on R2A agar within $48 \mathrm{~h}$ when incubated at $30{ }^{\circ} \mathrm{C}$. Growth occurred at temperatures ranging from 15 to $37^{\circ} \mathrm{C}$, but no growth was observed at $42{ }^{\circ} \mathrm{C}$ or at temperatures below $10{ }^{\circ} \mathrm{C}$. Growth occurred at $\mathrm{pH}$ 6-9, but no growth was observed at $\mathrm{pH} 5$ or 10 . The colonies were creamy white to yellowish, translucent, convex and circular with entire edges. Cells were Gram-negative-staining, catalase and oxidase-positive and were motile rods with a polar flagellum. Detailed physiological and biochemical characteristics are summarized in Table 1 and in the species description.

The only respiratory quinone was ubiquinone Q-8. The predominant fatty acids were $\mathrm{C}_{15: 0}$ iso $(26.76 \%), \mathrm{C}_{16: 0}$ iso
$(24.51 \%), \mathrm{C}_{17: 0}$ iso $\omega 9 c(20.54 \%)$ and $\mathrm{C}_{11: 0}$ iso $3-\mathrm{OH}$ $(7.43 \%)$. The entire fatty acid profile is available in Table S1. The polar lipids were composed of diphosphatidylglycerol, phosphatidylethanolamine, phosphatidylglycerol, phosphatidylmethylethanolamine, an unknown aminolipid and two unknown phospholipids; a two-dimensional TLC of the polar lipids from strain $\mathrm{T} 7-07^{\mathrm{T}}$ is available in Fig. S1 (in IJSEM Online).

The almost-complete 16S rRNA gene sequence (approx. $1480 \mathrm{nt}$ ) of strain $\mathrm{T} 7-07^{\mathrm{T}}$ was determined and compared with those of representative species within the genus Arenimonas (Fig. 1). Strain $77-07^{\mathrm{T}}$ showed the highest similarity to A. malthae CC-JY- $1^{\mathrm{T}}$, with value of $98.6 \%$ and low levels of sequence similarity to $A$. composti KCTC $12666^{\mathrm{T}}$, A. donghaensis KACC $11381^{\mathrm{T}}$ and A. oryziterrae KACC $14607^{\mathrm{T}}$, with values of $95.9 \%, 95.1 \%$ and $94.5 \%$, respectively. Strain $\mathrm{T} 7-07^{\mathrm{T}}$ showed similarity values of 82.3-92.2\% with other representative species within the family Xanthomonadaceae. The DNA-DNA hybridization level between strains T7-0 $7^{\mathrm{T}}$ and A. malthae CC-JY- $1^{\mathrm{T}}$ was $22.2 \%$, which was well below the $70 \%$ cut-off point recommended for the delineation of genomic species (Wayne et al., 1987).

On the basis of $16 \mathrm{~S}$ rRNA gene dissimilarity to related taxa and a phylogenetically distinct position, together with distinctive phenotypic characteristics and low levels of genomic relatedness, strain $\mathrm{T} 7-07^{\mathrm{T}}$ represents a novel species, for which the name Arenimonas daejeonensis sp. nov. is proposed. 


\section{Description of Arenimonas daejeonensis sp. nov.}

Arenimonas daejeonensis (dae.je.on.en'sis. N.L. fem. adj. daejeonensis pertaining to Daejeon, a city in South Korea, from where the type strain was isolated).

Cells are Gram-negative-staining, non-spore-forming, motile rods $(0.4-0.5 \times 1.0-1.5 \mu \mathrm{m})$ with a polar flagellum. Good growth is observed on R2A agar and nutrient agar but not on tryptic soy agar. Growth occurs at $15-37{ }^{\circ} \mathrm{C}$ (optimum $30{ }^{\circ} \mathrm{C}$ ) and at $\mathrm{pH}$ 6-9 (optimum $\mathrm{pH}$ 7). Growth occurs in the presence of 1 and $3 \%(w / v) ~ N a C l$, but not in concentrations above $4 \%$. Colonies are creamy white to yellowish, translucent, convex and circular with entire edges. Oxidase- and catalase-positive. Hydrolyses casein and DNA but does not hydrolyse chitin, starch, cellulose or xylan. Positive result in tests for arginine dihydrolase and urease activities, but negative results for nitrate and nitrite reduction, indole production, glucose fermentation, aesculin hydrolysis, gelatin hydrolysis and $\beta$-galactosidase (API 20NE test strip). Positive result for the following enzyme activities (API ZYM test strip): acid phosphatase, alkaline phosphatase, $\alpha$-chymotrypsin, esterase (C4), esterase lipase (C8), leucine arylamidase, naphthol-AS-BI-phosphohydrolase and trypsin, but negative result for the following enzyme activities: $N$-acetyl$\beta$-glucosaminidase, cystine arylamidase, $\alpha$-fucosidase, $\alpha$ galactosidase, $\beta$-galactosidase, $\alpha$-glucosidase, $\beta$-glucosidase, $\beta$-glucuronidase, $\alpha$-mannosidase, lipase (C14) and valine arylamidase. Acid is produced from 5-ketogluconate (weakly), but not from $\mathrm{N}$-acetylglucosamine, adonitol, aesculin, amygdalin, D-arabinose, L-arabinose, D-arabitol, L-arabitol, arbutin, cellobiose, dulcitol, erythritol, fructose, D-fucose, L-fucose, galactose, gentiobiose, gluconate, glucose, glycerol, glycogen, inositol, inulin, 2-ketogluconate, lactose, D-lyxose, maltose, mannitol, mannose, melezitose, melibiose, methyl $\alpha$-D-glucoside, methyl $\alpha$-D-mannoside, methyl $\beta$-D-xylose, raffinose, rhamnose, ribose, salicin, sorbitol, sorbose, starch, sucrose, D-tagatose, trehalose, Dturanose, xylitol, D-xylose or L-xylose. Assimilates L-alaninamide, L-alanine, L-alanyl glycine, L-asparagine (weakly), L-aspartic acid (weakly), L-glutamic acid, glycyl L-aspartic acid, glycyl L-glutamic acid, $\beta$-hydroxybutyric acid, Lproline, pyruvic acid methyl ester (weakly), succinamic acid (weakly), succinic acid monomethyl ester (weakly), Lthreonine (weakly), Tween 40 (weakly) and Tween 80 (weakly) and does not assimilate acetic acid, $\mathrm{N}$-acetyl-Dgalactosamine, $\mathrm{N}$-acetyl-D-glucosamine, cis-aconitic acid, adonitol, D-alanine, $\gamma$-aminobutyric acid, 2-aminoethanol, L-arabinose, L-arabitol, bromosuccinic acid, 2,3-butanediol, DL-carnitine, D-cellobiose, citric acid, $\alpha$-cyclodextrin, dextrin, i-erythritol, formic acid, D-fructose, L-fructose, Dgalactonic acid lactone, D-galactose, D-galacturonic acid, gentiobiose, D-glucuronic acid, D-glucosaminic acid, $\alpha$-Dglucose, $\alpha$-D-glucose 1-phosphate, D-glucose 6-phosphate, glucuronamide, D-glucuronic acid, glycerol, DL- $\alpha$-glycerol phosphate, glycogen, L-histidine, hydroxy-L-proline, $\alpha$-hydroxybutyric acid, $\gamma$-hydroxybutyric acid, $p$-hydroxyphenylacetic acid, inosine, myo-inositol, itaconic acid, $\alpha$-ketobutyric acid, $\alpha$-ketoglutaric acid, $\alpha$-ketovaleric acid, DL-lactic acid, $\alpha$-D-lactose, lactulose, L-leucine, malonic acid, maltose, Dmannitol, D-mannose, D-melibiose, methyl $\beta$-D-glucoside, L-ornithine, L-phenylalanine, phenylethylamine, propionic acid, D-psicose, putrescine, L-pyroglutamic acid, quinic acid, D-raffinose, L-rhamnose, D-saccharic acid, sebacic acid, D-serine, L-serine, D-sorbitol, succinic acid, sucrose, thymidine, D-trehalose, turanose, uridine, urocanic acid or xylitol (Biolog GN2 system). Susceptible to kanamycin and neomycin. Resistant to ampicillin, erythromycin, penicillin $\mathrm{G}$ and streptomycin. The major respiratory quinone is ubiquinone $\mathrm{Q}-8$. The predominant fatty acids are $\mathrm{C}_{15: 0}$ iso, $\mathrm{C}_{16: 0}$ iso, $\mathrm{C}_{17: 0}$ iso $\omega 9 c$ and $\mathrm{C}_{11: 0}$ iso $3-\mathrm{OH}$.

The type strain, $\mathrm{T} 7-07^{\mathrm{T}}\left(=\mathrm{KCTC} 12667^{\mathrm{T}}=\mathrm{DSM} 18060^{\mathrm{T}}\right)$, was isolated from compost. The $\mathrm{G}+\mathrm{C}$ content of the genomic DNA is $68.3 \mathrm{~mol} \%$.

\section{Acknowledgements}

This work was supported by the 21C Frontier Microbial Genomics and Application Center Program, Ministry of Science \& Technology (Grant MG08-0101-2-0), Republic of Korea.

\section{References}

Aslam, Z., Park, J. H., Kim, S. W., Jeon, C. O. \& Chung, Y. R. (2009). Arenimonas oryziterrae sp. nov., isolated from a field of rice (Oryza sativa L.) managed under a no-tillage regime, and reclassification of Aspromonas composti as Arenimonas composti comb. nov. Int J Syst Evol Microbiol 59, 2967-2972.

Atlas, R. M. (1993). Handbook of Microbiological Media. Edited by L. C. Parks. Boca Raton, FL: CRC Press.

Bates, R. G. \& Bower, V. E. (1956). Alkaline solutions for pH control. Anal Chem 28, 1322-1324.

Ezaki, T., Hashimoto, Y. \& Yabuuchi, E. (1989). Fluorometric deoxyribonucleic acid-deoxyribonucleic acid hybridization in microdilution wells as an alternative to membrane filter hybridization in which radioisotopes are used to determine genetic relatedness among bacterial strains. Int J Syst Bacteriol 39, 224-229.

Felsenstein, J. (1985). Confidence limits on phylogenies: an approach using the bootstrap. Evolution 39, 783-791.

Gerhardt, P., Murray, R. G. E., Wood, W. A. \& Krieg, N. R. (editors) (1994). Methods for General and Molecular Bacteriology. Washington, DC: American Society for Microbiology.

Gomori, G. (1955). Preparation of buffers for use in enzyme studies. Methods Enzymol 1, 138-146.

Groth, I., Schumann, P., Weiss, N., Martin, K. \& Rainey, F. A. (1996). Agrococcus jenensis gen. nov., sp. nov., a new genus of actinomycetes with diaminobutyric acid in the cell wall. Int J Syst Bacteriol 46, 234239.

Hall, T. A. (1999). BioEdit: a user-friendly biological sequence alignment editor and analysis program for Windows 95/98/NT. Nucleic Acids Symp Ser 41, 95-98.

Jin, L., Kim, K. K., Im, W. T., Yang, H. C. \& Lee, S. T. (2007). Aspromonas composti gen. nov., sp. nov., a novel member of the family Xanthomonadaceae. Int J Syst Evol Microbiol 57, 1876-1880.

Kane, B. E. \& Mullins, J. T. (1973). Thermophilic fungi in a municipal waste compost system. Mycologia 65, 1087-1100. 
Kimura, M. (1983). The Neutral Theory of Molecular Evolution. Cambridge: Cambridge University Press.

Kumar, S., Tamura, K. \& Nei, M. (2004). MEGA3: Integrated software for Molecular evolutionary genetics analysis and sequence alignment. Brief Bioinform 5, 150-163.

Kwon, S. W., Kim, B. Y., Weon, H. Y., Baek, Y. K. \& Go, S. J. (2007). Arenimonas donghaensis gen. nov., sp. nov., isolated from seashore sand. Int J Syst Evol Microbiol 57, 954-958.

Lajudie, J. (1956). [Study on thermophilic soil microflora. I. Technics]. Ann Inst Pasteur (Paris) 91, 778-780 (in French).

Minnikin, D. E., Patel, P. V., Alshamaony, L. \& Goodfellow, M. (1977) Polar lipid composition in the classification of Nocardia and related bacteria. Int J Syst Bacteriol 27, 104-117.

Moriya, T., Hikota, T., Yumoto, I., Ito, T., Terui, Y., Yamagishi, A. \& Oshima, T. (2011). Calditerricola satsumensis gen. nov., sp. nov. and Calditerricola yamamurae sp. nov., extreme thermophiles isolated from a high-temperature compost. Int J Syst Evol Microbiol 61, 631636.

Rainey, F. A., Ward-Rainey, N., Kroppenstedt, R. M. \& Stackebrandt, E. (1996). The genus Nocardiopsis represents a phylogenetically coherent taxon and a distinct actinomycete lineage: proposal of Nocardiopsaceae fam. nov. Int J Syst Bacteriol 46, 1088-1092.

Saitou, N. \& Nei, M. (1987). The neighbor-joining method: a new method for reconstructing phylogenetic trees. Mol Biol Evol 4, 406-425.

Sasser, M. (1990). Identification of bacteria by gas chromatography of cellular fatty acids, MIDI Technical Note 101. Newark, DE: MIDI Inc.
Tamaoka, J. \& Komagata, K. (1984). Determination of DNA base composition by reversed-phase high-performance liquid chromatography. FEMS Microbiol Lett 25, 125-128.

Tarrand, J. J. \& Gröschel, D. H. M. (1982). Rapid, modified oxidase test for oxidase-variable bacterial isolates. J Clin Microbiol 16, 772774 .

Ten, L. N., Im, W.-T., Kim, M.-K., Kang, M. S. \& Lee, S.-T. (2004). Development of a plate technique for screening of polysaccharidedegrading microorganisms by using a mixture of insoluble chromogenic substrates. J Microbiol Methods 56, 375-382.

Thompson, J. D., Gibson, T. J., Plewniak, F., Jeanmougin, F. \& Higgins, D. G. (1997). The CLUSTAL_X windows interface: flexible strategies for multiple sequence alignment aided by quality analysis tools. Nucleic Acids Res 25, 4876-4882.

Wayne, L. G., Brenner, D. J., Colwell, R. R., Grimont, P. A. D., Kandler, O., Krichevsky, M. I., Moore, L. H., Moore, W. E. C., Murray, R. G. E. \& other authors (1987). International Committee on Systematic Bacteriology. Report of the ad hoc committee on reconciliation of approaches to bacterial systematics. Int J Syst Bacteriol 37, 463-464.

Winker, S. \& Woese, C. R. (1991). A definition of the domains Archaea, Bacteria and Eucarya in terms of small subunit ribosomal RNA characteristics. Syst Appl Microbiol 14, 305-310.

Young, C. C., Kämpfer, P., Ho, M. J., Busse, H. J., Huber, B. E., Arun, A. B., Shen, F. T., Lai, W. A. \& Rekha, P. D. (2007). Arenimonas malthae sp. nov., a gammaproteobacterium isolated from an oilcontaminated site. Int J Syst Evol Microbiol 57, 2790-2793. 